\title{
Multiplication VS Inverse Division Strategy in Grade V Elementary School Students
}

\author{
Vembe Andy Romaeta ${ }^{1}$, Mugi Rahayu ${ }^{2}$, Nofita Sari ${ }^{3}$, Ahmad $^{4}$ \\ $\left\{\right.$ vembeandy33@gmail.com ${ }^{1}$, mugirahayu185@gmail.com ${ }^{2}$, nofitasari1979@gmail.com ${ }^{3}$, \\ ahmad@ump.ac.id $\left.{ }^{4}\right\}$ \\ ${ }^{1,3}$ SDN 3 Grendeng, Banyumas \\ ${ }^{2}$ SDN 2 Tangkisan, Purbalingga \\ 1,2,3,4 Master of Basic Education, Universitas Muhammadiyah Purwokerto
}

\begin{abstract}
Researchers conduct this study is based on a desire to explore the ability to count 'porogapet' and other aritmatika students in sixth-grade primary school, especially in the strategy division of the inverse of multiplication. The background so that teachers can guide students to develop their abilities and skills to overcome the problems they face. The type of data used is secondary data. The data collection method is a literature study. The method that will be used for this study is a literature study. Study results that the ability of students to count porogapet and other arithmetic problems with the inverse division approach of multiplication requires the ability to understand the concept of multiplication properly and correctly. The teacher must present it in an enjoyable, iconic, and symbolic way. The application of the inverse division strategy of multiplication has implications for increasing competence, namely : (1) being creative in problem-solving, (2) being able to connect between concepts, (3) being able to explore promissory notes, (4) being able to connect in two directions (reversible). The researcher conducted this study based on the desire to explore whether counting porogapet and other arithmetic could use the strategy of dividing the opposite of multiplication? And what are the implications for the numeracy skills of grade V elementary school students, especially in the inverse division of multiplication.
\end{abstract}

Keywords: Division, Multiplication, Students' Ability

\section{Introduction}

In the goals and functions of national education, it is emphasized that students are expected to have the skills they need, especially in this 4.0 era, namely quality humans who can answer new challenges to create breakthrough thinking processes. Students after obtaining their education can develop their abilities and skills to overcome the problems they face without leaving a noble character. Like music, mathematics is a personality-building activity, it shapes the way students think and see the world [1] . Learning activities in elementary schools generally use conventional learning models [2]. The researcher chose the research to calculate mathematics with the inverse division strategy of multiplication in porogapet and other arithmetic problems. So with this strategy, it can shift conventional learning. 


\section{Porogapet and the Contradiction of Multiplication Strategy}

The researcher assumes that to solve the porogapet problem using a division strategy as opposed to multiplication, with the understanding that students have already strongly understood the concept of multiplication compared to the concept of division. So that the next step in calculating porogapet can find the connection correctly. The advantage of students is to continue understanding existing concepts. The researcher assumes that by providing adequate knowledge of numeracy, students can be creative in solving problems for porogapet questions and other arithmetic problems in the form of non-porogapet division. For students to get good learning outcomes to the next level, students must master the concepts of multiplication and division well. To instill the concept of counting, it is necessary to do teaching that allows students to better understand the concept. So that the presentation in an enactive, iconic, and symbolic way needs to be done to make it easier for someone to understand the concept. The researcher concludes that students are creative in problemsolving by thinking about the relationship between events in two directions.

Table.1 Summary of Problems Regarding Education

\begin{tabular}{cc}
\hline \multicolumn{1}{c}{ Main Problem } & Description \\
\hline Predictability on division & $\begin{array}{c}\text { According to students, division is more difficult } \\
\text { than addition, subtraction, and multiplication [4]. }\end{array}$ \\
The right teaching strategy & For grades 4,5 and 6 they already understand the \\
& concept of numbers, they are saturated using visual \\
Creative thinking skills & aids [4] \\
& At the elementary school level, there are student \\
Critical thinking skills & Studerstandings [8]
\end{tabular}

Deswita reported that division is more difficult to learn than addition, subtraction, multiplication because in thinking of division there is a guessing step [3]. Thus, to help students who do not understand the estimation step because they do not know the division (mentally) in calculating porogapet using the inverse division approach from multiplication, they have strong reasons [4]. Meanwhile, if the teaching aids are used in grade 6 elementary school students they already have the concept of numbers so they feel bored. Therefore, the inverse division approach of multiplication is used to work on porogapet problems. She statement is in line with Hiebert and Carpenter (1992) in Qadri Ali Hasan explains

The growth of understanding using the terms "adjoining" and "reorganizing" in an existing framework. Adjoining can occur when students have an awareness of a mathematical idea for the first time. Reorganizing occurs when students try to understand the mathematical idea, students explore/look for connections into existing mental representations [5].

The researcher thinks that this opinion strengthens the reason for the researcher to solve the porogapet problem using the division approach as opposed to multiplication, with the understanding 
that students have already strongly understood the concept of multiplication compared to the concept of division. So that the next step in calculating porogapet can find the connection correctly. The advantage of students is to continue understanding existing concepts.

LeFevre and Morris reported that it was proposed identical element model of an arithmetic solution so that items that share the operand and sign of the operation (eg, $6 \times 8$ and $8 \times 6$ ) are processed with the same representation, whereas items that do not share all three elements (eg, 48 i - 6 and $48-;-8)$ processed through different representations. Therefore, according to the identical element model, 8 X 6 and 48 -;-6 will be processed in an independent mental structure. Division and multiplication facts are stored in independent representations but solving such problems often involves access to knowledge of multiplication [7].

Lusiana et al. reported the profile of creative thinking of students with high logicalmathematical intelligence in solving mathematical problems. The creativity studied is the creativity stage that appears at every stage of problem-solving, so that the creativity profile of students with high logical-mathematical intelligence in solving linear equation system problems is presented at each problem-solving step [8]. They uses contextual-based linear equations while researchers use division approach the opposite of multiplication to work on porogapet questions, but both have similarities, namely in the scope of arithmetic material so that researchers assume by providing adequate knowledge of arithmetic division students can be creative in problem-solving for porogapet questions and other arithmetic problems in the form of division instead.

Gonzales examined the basic knowledge of science in elementary school students, that Our study of the data revealed that similar misconceptions are seen in upper elementary school students and lower elementary school students. So that researchers feel it is important to prepare the right strategies on the right subjects [9]. The development of creative thinking skills needs to be done because this ability is one of the skills desired by the world of work [10]

Skemp in Mawaddah and Maryanti revised his categorization and definition of understanding to include components of formal understanding, in addition to instrumental understanding and relational understanding [11]. He defines:

"Instrumental understanding is the ability to apply an appropriate remembered rule to the solution of a problem without knowing why the rule works. Relational understanding is the ability to deduce specific rules or procedures from more general mathematical relationships.

So according to Skemp, understanding is an ability. He classifies student understanding based on the abilities of students, students are said to be able to understand instrumentally if students can recall things that are included in this level are knowledge of basic facts, terms, using routine things.

The indications are that students can reiterate, write, identify, sort, select, show, state, and calculate, simplify, solve routine problems and others that essentially students know the use of concepts they have received even though students do not understand why it is done so. The next level is relational understanding. At this level, students can correctly apply a general mathematical idea to specific things or new situations. This level indicates that students can use, apply, relate, generalize, organize, and clarify. The next level is formal understanding. At this level, students can describe a problem into more detailed parts and can understand the relationship between these parts. Besides that, students are also able to combine parts logically into a new structural pattern, considering a situation, idea, method based on benchmarks or criteria. Indications of this ability 
include students being able to logically link, prove, find, classify, conclude, criticize, formulate, validate, and determine.

There are 4 (four) basic arithmetic operations on whole numbers, these four arithmetic operations are addition, subtraction, multiplication, and division [12]. Mastery of basic arithmetic operations is very important because these operations will be the basis for those who want to learn mathematics, therefore the concept of counting must be truly understood by those who will learn mathematics. To instill the concept of counting, it is necessary to do teaching that allows students to better understand the concept. So that the presentation in an enactive, iconic, and symbolic way needs to be done to make it easier for someone to understand the concept. Among the four arithmetic division operations are the most difficult to learn [13]. The area of cognitive arithmetic deals with the mental processes and structures used to perform simple arithmetic operations such as addition and multiplication [14].

Given the importance of mastering the concept of counting, the concept of counting needs to be mastered by students. This counting concept needs to be strengthened in elementary school students so that in subsequent learning at a higher level students do not have difficulty counting. Required the researchers an- researchers an intensive due to errors in workmanship students different matter. By examining his mistakes, his understanding was improved according to the types of errors he experienced. Deswita explained

One of the mathematical concepts taught in the fourth grade of elementary school is the concept of division. Students can understand the concept of division through the concept of multiplication. The concept of multiplication and division is one of the basic capital of students for the next concept level even up to college.

This is by the nature of mathematics which is a structured science. For students to get good learning outcomes to the next level, students must master the concepts of multiplication and division well.

Tirosh and Tsamir reported

the conceptual change approach to mathematics learning and teaching" is an attempt to explore the promises for mathematics education of the conceptual change framework, which is widely used in science education.

A particular issue: the 'conceptual change approach to learning and teaching mathematics is an attempt to explore the premise for mathematics education of the conceptual change framework, which is widely used in science education. The researcher agrees with the opinion of them by exploring the promise in learning and teaching mathematics to solve specific problems. So that students get adequate knowledge to think creatively in problem-solving [15]. Students think productively and think critically. [16]

Maf'ulah et al. making equations are part of reversible thinking skills or in Piaget's theory commonly referred to as reversibility. To quote Inhelder \& Piaget (1958)

reversibility is the ability to think about the relationship between events in two directions. This meaning can be interpreted as a person's mental ability to build a two-way relationship. Reversibility is a person's mental ability to change the direction of his thinking so that it can return to its original point. 
In line with Piaget, Kang and Lee support reversibility. Quoting Kang and Lee said through reversibility, students can recognize problems in various ways, because reversibility is an important factor in creative problem solving, which is closely related to flexible thinking ". So that the equations made by the subject are a form of the subject's ability to recognize problems in various ways. [17]

This research reinforces the researcher's assumption that students are creative in problemsolving by thinking about the relationship between events in two directions. This supports the statement that division is the opposite of multiplication, as a reversible way of thinking. The frequency of non-genuine confusion errors (eg 9 × $6=36$ ) is used to measure the similarity factor. Problem nodes continue to receive similar input-based stimuli during retrieval and compete in a mutually inhibiting manner until one node reaches a critical activation threshold and triggers a response [17].

The form of division can be viewed as a form of multiplication operation with one of the unknown factors. For example, if in multiplication $3 \times 4=k$ of course $\mathrm{k}=12$ then, in division it can be stated in the form 12: $3=\mathrm{n}$ or 12: $4=\mathrm{n}$ Thus 12: $3=\mathrm{n}$ when expressed in multiplication form will become $12=\mathrm{n} \times 3$, while $12: 4=\mathrm{n}$ becomes the multiplication form to $12=\mathrm{n} \times 4$. To find the value of $\mathrm{n}$ from the form $12=\mathrm{n} \times 3$, it is the same as finding the answer to the question: which number when multiplied by 3 will produce 12 or what $12: 3$ ? These two questions will return the same number. So if the first question gets a score of 4 , it also means the value of $12: 3=4$.[18]

The researcher obtained the results to solve the porogapet problem using the opposite division strategy of multiplication, with the understanding that students had a stronger understanding of the concept of multiplication than the concept of division. So that the next step in calculating porogapet can find the connection correctly. The advantage of students is to continue understanding existing concepts. The researcher assumes that by providing adequate knowledge of arithmetic, students can be creative in problem-solving for porogapet questions and other arithmetic problems in the form of division instead of porogapet. So that students get good learning outcomes up to the next level, students must master the concepts of multiplication and division well. To instill the concept of counting, it is necessary to do teaching that allows students to better understand the concept. So that the presentation in an enactive, iconic, and symbolic way needs to be done to make it easier for someone to understand the concept. The researcher concludes that students are creative in problemsolving by thinking about the relationship between events in two directions.

\section{Conclusion}

Researchers concluded that the student's skills in numeracy porogapet and other arithmetic problems approach division right of multiplication requires requisite skills to understand the concept of multiplication properly. The teacher must present it in an enjoyable, iconic, and symbolic way. The application of the opposite division strategy of multiplication has implications for increasing competence, namely: (1) Creative in problem-solving; (2) Able to connect between concepts; (3) Able to explore promissory notes; and (4) Able bidirectional (reversible)

\section{References}

[1] Borovik A, Gardiner T. Mathematical abilities and mathematical skills. World Federation of National Mathematics Competitions Conference 2006 Cambridge, England 22-28 July 2006 
[2] Kurniawan D, Karlimah K, Suryana Y. Penerapan media komik matematika terhadap peningkatan pemahaman konsep perkalian dan pembagian bilangan cacah di sekolah dasar. JP3M (Jurnal Penelitian Pendidikan dan Pengajaran Matematika). 2015 Sep 30;1(1):1-6.

[3] Deswita H. Analisis Kesalahan Siswa Dalam Menyelesaikan Soal Pembagian Di Kelas IV Sekolah Dasar. Edu Research. 2015;4(2):115-20.

[4] Hamsinah H. Meningkatkan Hasil Belajar Matematika Siswa Kelas II Pada Materi Perkalian dan Pembagian Dengan Menggunakan Metode Resitasi Di SDN 359 Wonosari (Doctoral dissertation, UNIVERSITAS COKROAMINOTO PALOPO).

[5] Hasan QA. Pengembangan Pembelajaran Operasi Pembagian dengan Menekankan Aspek Pemahaman. Jurnal Pendidikan. 2017 Nov;18(2):106-14.

[6] LeFevre JA, Morris J. More on the relation between division and multiplication in simple arithmetic: Evidence for mediation of division solutions via multiplication. Memory \& cognition. 1999 Sep;27(5):803-12.

[7] Campbell JI. Mechanisms of simple addition and multiplication: A modified networkinterference theory and simulation. Mathematical cognition. 1995 Jan;1(2):121-64.

[8] Lusiana R, Murtafiah W, Oktafian F. Kemampuan Metakognitif Siswa dalam Menyelesaikan Permasalahan pada Materi Pola Bilangan Ditinjau dari Brain Dominance. AKSIOMA: Jurnal Program Studi Pendidikan Matematika. 2020 Dec 31;9(4):962-76.

[9] González FM. Diagnosis of Spanish primary school students' common alternative science conceptions. School Science and Mathematics. 1997 Feb;97(2):68-74.

[10] Ashcraft MH. Cognitive psychology and simple arithmetic: A review and summary of new directions. Mathematical cognition. 1995;1(1):3-4.

[11] Mawaddah S, Maryanti R. Kemampuan pemahaman konsep matematis siswa SMP dalam pembelajaran menggunakan model penemuan terbimbing (discovery learning). Edu-Mat: Jurnal Pendidikan Matematika. 2016 Apr;4(1).

[12] Surtini S. Problem Posing dan Pembelajaran Operasi Hitung Bilangan Cacah Siswa SD. 2003

[13] Zhao N, Valcke M, Desoete A, Burny E, Imbo I. Differences between Flemish and Chinese primary students' mastery of basic arithmetic operations. Educational Psychology. $2014 \mathrm{Nov}$ 10;34(7):818-37.

[14] Moma L. Pengembangan instrumen kemampuan berpikir kreatif matematis untuk siswa SMP. Delta-Pi: Jurnal Matematika dan Pendidikan Matematika. 2016 Oct 7;4(1).

[15] Tirosh D, Tsamir P. What can mathematics education gain from the conceptual change approach? And what can the conceptual change approach gain from its application to mathematics education?. Learning and Instruction. 2004;5(14):535-40.

[16] Newton DP, Newton LD. Some student teachers' conceptions of creativity in school science. Research in Science \& Technological Education. 2009 Apr 1;27(1):45-60.

[17] Kang MK, Lee BS. On Fuzzified Representation of Piagetian Reversible Thinking. Research in Mathematical Education. 1999;3(2):99-112.

[18] Kristiyono H. Mahir Perkalian dan Pembagian Bilangan Dasar Melalui Metode Permainan Kartu. Jurnal Pendidikan Penabur. 2008;7(10):1-0. 